\title{
Gastrointestinal bleeding due to large bowel infiltration by chronic lymphocytic leukaemia
}

\author{
John Tucker* and Philip G. Cachia
}

Department of Clinical and Laboratory Haematology, Western General Hospital, Edinburgh EH4 2XU, UK.

\begin{abstract}
Summary: A 66 year old woman with a 9 year history of chronic lymphocytic leukaemia developed intermittent rectal bleeding for 9 months; sigmoidoscopic biopsy proved that this was due to large bowel infiltration by leukaemia. This is a very rare occurrence.
\end{abstract}

\section{Introduction}

The presenting manifestations of chronic lymphocytic leukaemia (CLL) are usually due to infiltration of lymphoid organs; ensuing complications are mainly autoimmune phenomena and infections (Catovsky, 1984). We present a case of persistent lower gastrointestinal bleeding in a patient with CLL which was proved at biopsy to be due to massive rectal and colonic infiltration. This is a very rare complication, with only one previously reported case in English (Scharschmidt, 1978).

\section{Case report}

A 66 year old woman with B-cell CLL was transferred to our care in March 1984. This diagnosis had been made elsewhere in 1975 following a routine blood count. No treatment was given until February 1978 when her haemoglobin was $10.5 \mathrm{~g} / \mathrm{dl}$, total white count was $299 \times 10^{9} / 1$ (99\% lymphocytes) and platelet count was $200 \times 10^{9} / 1$. The spleen had become palpable, but there was no lymphadenopathy. Therapy mainly consisted of low dosage chlorambucil; in addition a $1638 \mathrm{~g}$ spleen was removed in January 1982 for thrombocytopenia (platelets less than $\left.10 \times 10^{9} / 1\right)$ and red cell transfusions had been required intermittently since August 1982.

Rectal bleeding began in August 1983, occasionally with passage of mucus, and was investigated in October 1983. Barium enema was negative, sigmoidoscopy and colonoscopy as far as the splenic flexure showed diffuse purpura and inflammation;

\footnotetext{
*Correspondence and present address: J. Tucker M.B., Ch.B., M.R.C.P.(UK), M.R.C.Path., Department of Medical Oncology, St Bartholomew's Hospital, West Smithfield, London EClA 7BE, UK.

Accepted: 16 April 1985
}

biopsies were not taken in view of thrombocytopenia (average platelet count $\left.40 \times 10^{9} / 1\right)$. There was some response to prednisolone enemas.

She was admitted in May 1984 with a 4 day history of bright red rectal bleeding up to 20 times per 24 hours. On examination she was unwell, thin and pale, with widespread bruising. The abdomen was soft and non-tender with no organs or masses palpable. Haemoglobin was $9.4 \mathrm{~g} / \mathrm{dl}$, white cell count $19.0 \times 10^{9} /$ 1 (97\% lymphocytes) and platelets $23 \times 10^{9} / 1$. Prothrombin time was $20 \mathrm{~s}$ (control $13 \mathrm{~s}$ ), activated partial thromboplastin time (Manchester Reagent) 60 s (control $45 \mathrm{~s}$ ), thrombin time $12 \mathrm{~s}$ (control $12 \mathrm{~s}$ ), fibrinogen (Ellis and Stransky) $4.0 \mathrm{~g} / \mathrm{l}$ (normal 2.0-4.0 g/l), fibrin degradation products $10-40 \mathrm{mg} / 1$ (normal less than $2.5 \mathrm{mg} / \mathrm{l}$ ). Stool culture and microscopy were negative. After platelet transfusion sigmoidoscopy was performed: the mucosa was intensely congested with spontaneous bleeding and ulceration between $0-12 \mathrm{~cm}$ from the anus. From $13-20 \mathrm{~cm}$ the mucosa was only slightly swollen, with surface blood from more distal bleeding. Multiple rectal and colonic biopsies all showed extensive infiltration by CLL with superficial ulceration (see Figure 1). Subsequent therapy was only palliative. She deteriorated and died. Permission for post-mortem examination was refused.

\section{Discussion}

CLL is directly responsible for the death of the patient in approximately $36 \%$ of cases (Boggs et al., 1966). Many non-lymphoid organs may be infiltrated at autopsy, but in vivo manifestations are uncommon. An autopsy survey of 148 patients with leukaemia included 18 cases of CLL (Prolla \& Kirsner, 1964). Large bowel lesions were present in 7 of these 18 , with 4 cases of mucosal haemorrhages and 3 cases of leukaemic

(C) The Fellowship of Postgraduate Medicine, 1986 


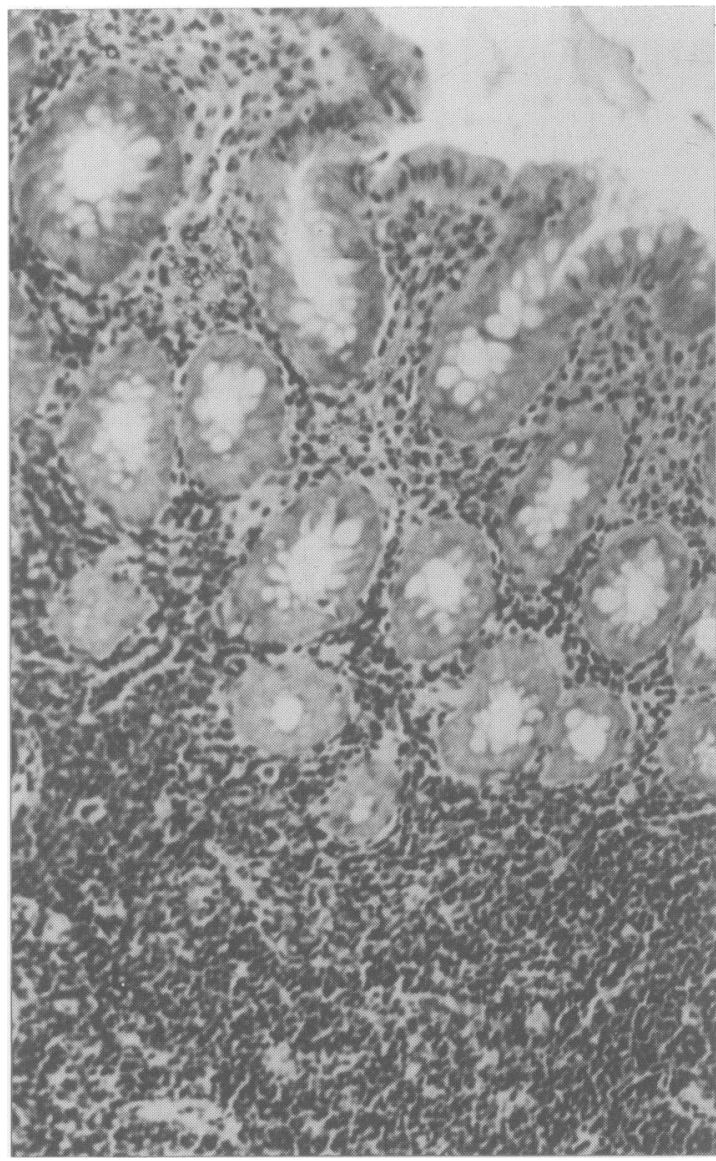

Figure 1 Sigmoidoscopic biopsy at $10 \mathrm{~cm}(\times 100)$ showing lymphocytic infiltrate.

\section{References}

BOGGS, D.R., SOFFERMAN, S.A., WINTROBE, M.M. \& CARTWRIGHT, G.E. (1966). Factors influencing the duration of survival of patients with chronic lymphocytic leukemia. American Journal of Medicine, 40, 243.

CATOVSKY, D. (1984). Chronic lymphocytic prolymphocytic and hairy cell leukaemias. In Leukaemias, Goldman, J.M. and Priesler, H.D. (eds). Butterworths International Medical Reviews. Haematology p. 266. infiltrates; there was no mention of symptoms. Thepe is one other case in the English-spoken literature of bowel infiltration with CLL causing problems in liê, with symptoms of haemorrhagic colitis (Scharschmidt, 1978). In our case there were abnormalities of coagulation tests consistent with hepatic disease, affd longstanding thrombocytopenia, but we attribute tre major cause of the rectal bleeding to biopsy-prove extensive bowel infiltration with CLL.

\section{Acknowledgements}

㐫

We thank Mrs Patricia Stewart for typing the manuscript, $\overrightarrow{\mathrm{P}_{\mathrm{r}}}$ W. Sircus for performing the sigmoidoscopy biopsies, $\mathrm{Dr} \mathscr{W}$. Busuttil for providing photomicrographs, and Dr G. Stocki and Dr D.K. Goff for permission to report this case.

PROLLA, J.C. \& KIRSNER, J.B. (1964). The gastro-intestion lesions and complications of the leukemias. Annals Internal Medicine, 61, 1084.

SCHARSCHMIDT, B.F. (1978). Chronic lymphocytic leut. emia presenting as colitis. American Journal of Digestiue Diseases, 23, 9. (n) . 